\title{
Social determinants of nutrient intake in smokers and non-smokers during pregnancy
}

\author{
F M Haste, O G Brooke, H R Anderson, J M Bland, J L Peacock
}

\begin{abstract}
Study objective-The aim was to investigate the effects of social factors (education, income, marital status, partners' employment status, housing tenure, social class), smoking, and maternal height on the dietary intake of pregnant women.
\end{abstract}

Design-The study was a prospective investigation on a two phase sample.

Setting-The study involved women attending the antenatal clinic at a district general hospital.

Patients-A group of pregnant Caucasian women, selected because they were heavy smokers $(15+$ cigarettes/day) $(n=94)$ and a randomly selected sample of never smokers ( $n=112)$ were studied.

Measurements and main results-Data on social factors were collected by interviewer administered questionnaire. $A$ 7 day weighed intake method was used to determine dietary intake at 28 weeks gestation. In univariate analyses, income, housing tenure and social class had significant effects on intakes of both macroand micronutrients, and maternal education and smoking had significant effects on intakes of micronutrients. Using a stepwise multivariate analysis with income, smoking and maternal education, income was a significant factor in the intake of most nutrients but this effect disappeared when social class and housing tenure factors were entered into the model. Only social class and housing tenure had any significant effect on intakes of macronutrients-energy, protein and fat. Smoking and maternal education were the most important determinants of quality of diet (nutrient density); other factors had only negligible effects. Income was the only significant factor in alcohol intake. It is suggested that the effects of social class and income are overlapping.

Conclusions-Smoking, being renters of accommodation, and being of minimum education and low social class are risk factors for poor dietary intake. It is recommended that such higher risk groups be specifically targeted for nutritional advice in pregnancy.

Several studies have reported social class variation in dietary intake during pregnancy in Britain. ${ }^{1-3}$ We have also reported that smoking and social class have independent effects on dietary intake in pregnancy. ${ }^{4}$ In the general population dietary intake has been found to vary by region, family size, income, housing tenure, ${ }^{5}$ maternal education, and social class. ${ }^{6}$

There has been increasing interest in recent years in the effects of diet on overall health, both in terms of specific diseases, eg, coronary heart disease, ${ }^{7}$ cardiovascular diseases, ${ }^{8}$ diabetes, ${ }^{9}$ cancer, ${ }^{10}$ and in terms of general well being. ${ }^{11}$ Some of the variation in mortality by social class may be due to corresponding variation in dietary intake. Considerable work has been done in pregnancy on the influence of individual nutrients on fetal growth ${ }^{12}$ and pregnancy outcome (vitamin $C_{,}^{13}$ folate, ${ }^{14-16}$ zinc, $^{17-21}$ energy ${ }^{22}$ ). Long term studies have indicated an association between reduced fetal growth and reproductive performance and periods of economic decline. ${ }^{23}$ Dietary studies of low income, high risk women suggest links between poor diets and poor fetal outcome. ${ }^{24}$

While associations between diet and general social factors, eg, social class, can provide broad indications of sources of variation they do not explain relationships, nor do they give sufficient information for particular at risk groups to be identified. We have set out to examine the effects of certain social factors that may have a direct effect on dietary intake. We have chosen the following factors: (1) those that might determine availability in the marketplace, ie, income, which may also be affected by employment status (working or not working) and marital status (single or supported); (2) factors that may determine choice, particularly of dietary quality, ie, maternal education; (3) smoking, which may act as an appetite or taste suppressant or otherwise influence quantity or quality of diet.

We have also considered social class and housing tenure as general social categories, to examine whether the effects of these general social factors are mediated by variation in factors 1-3.

\section{Methods}

The study was carried out at St George's Hospital, Tooting, London. All white women presenting at the antenatal booking clinics from August 1982 to August 1984 were given a structured questionnaire by trained interviewers to obtain details of smoking habit. These methods have been reported elsewhere. ${ }^{25}$ Sixty eight per cent of the population were non-smokers at booking, and $10 \%$ reported smoking $15+$ cigarettes/day. All women who reported smoking $\geqslant 15$ cigarettes/day in the previous week were selected for the smoking group. Non-smokers were selected using random number tables, from women who reported that they had never smoked. 
Information on income, social class, marital status, education, and housing tenure was obtained by the interviewers at the second antenatal visit and at 28 weeks. Social class was categorised according to the Registrar General's classification, ${ }^{26}$ using the occupation of the woman's partner if she was married or cohabiting, or her own occupation if single and unsupported.

Details of methods of weighed dietary intake have been reported elsewhere. ${ }^{4}$ Women were asked to weigh all their food and drink consumed for seven days and were visited at least three times during the week by a field worker to ensure that recording was accurate. Data used were means of seven day recorded intakes, and were analysed using McCance and Widdowson's The composition of foods. ${ }^{27}$ Caffeine consumption was estimated using an average estimation of caffeine content per cup of tea, coffee, chocolate, and cola drinks. ${ }^{28-30}$ One hundred and thirty nine smokers and 149 non-smokers were asked to participate in the study. Complete diary data were obtained for 94 smokers $(68 \%)$ and 112 non-smokers $(75 \%)$.

\section{STATISTICAL ANALYSIS}

For the purposes of analysis, dietary variables which did not have an approximately normal distribution were logarithmically transformed. One or two way analysis of variance was used to test the significance of factors on raw or transformed data where appropriate. Stepwise multiple regression analysis was performed using SPSS-X, using an entry criterion of significance for $F$ of $p<0.05$, and a removal criterion of significance of $p<0 \cdot 1$. This procedure sequentially removes variables in order of significance, then re-enters the variables, recalculating the model at each step, until no further change in the model occurs.

Standardised regression coefficient $(\beta)$ has been used, where the coefficient is standardised to the number of standard deviations change in $y$ associated with 1 standard deviation change in $x$, using the equation:

$$
\beta x y=B x y(s d x / s d y)
$$

where $B$ is the regression coefficient, and sdx and sdy are the standard deviations of $x$ and $y$. This is to enable comparison to be made between coefficients which have different initial units.

\section{Results}

Smokers had different characteristics from nonsmokers in that they were more likely to be less educated and to be on lower incomes, and were less likely to be owner-occupiers. Smokers' partners were more often in manual occupations and unemployed. Within each of the above social categories smokers were more likely to be at the lower end (table I); thus within non-manual occupations smokers were significantly less likely to be owner occupiers, to have higher education, or to have partners in employment; within manual occupations smokers were significantly less likely to have educational qualifications. Smokers were shorter than non-smokers overall, mean height being $160.6($ SD 6.0$) \mathrm{cm} v 163.7(5.4) \mathrm{cm}$, $\mathrm{p}<0.001$, and they were shorter within each social category, although these latter differences were not significant (data not shown).

Dietary intake of many nutrients (including energy) was significantly correlated with maternal height; therefore height was controlled for in the analyses where appropriate.

\section{Income}

When considered on its own (after controlling for maternal height) income had a highly significant effect on the intake of all nutrients (table II). Women with the highest income had the greatest intake of all nutrients except carbohydrate, and those with the lowest incomes had the lowest intakes. Mean alcohol intake was greatest in the higher income groups.

\section{MATERNAL EDUCATION}

Three categories of educational qualifications were used-higher (post " $O$ " level), intermediate (any up to and including "O" level), or none. Increasing level of maternal education was significantly associated with increased consumption of micronutrients (minerals and vitamins) (table III). Energy, fat, and carbohydrate intakes did not differ between groups after maternal height had been allowed for. Mean alcohol intake was greater in women with higher education, while caffeine intake increased as maternal education decreased.

\section{MARITAL STATUS}

Marital status was defined as single (unsupported) or partnered (married or cohabiting). Ten percent $(n=19)$ of the sample were single women. Compared to partnered women single women had significantly lower intakes of many nutrients, particularly macronutrients (energy, protein, fat, and carbohydrate).

\section{PARTNER'S EMPLOYMENT STATUS}

Women whose partners were not working had lower intakes of fibre, iron, and vitamin $E$ than women whose partners were in employment.

\section{HOUSING TENURE}

Tenure was classified as owning or renting. Owner-occupiers had significantly higher intakes of all nutrients except carbohydrate $(p<0.01$, after controlling for maternal height).

\section{SMOKING}

Non-smokers had higher intakes of protein and of all micronutrients than smokers, but there was no significant difference in intakes of energy, fat or carbohydrate between smokers and non-smokers. Data on the partnered women in this population have been presented elsewhere; ${ }^{4}$ inclusion of single women in the analysis slightly strengthened the significance of the differences between smokers and non-smokers. Mean caffeine intake of smokers was almost double that of nonsmokers, at 477 (224) $v 260$ (129) $\mathrm{mg} / \mathrm{d}, \mathrm{p}<0.001$. Mean alcohol intake, although higher in smokers, was not significantly different to that of non-smokers, at $3.9(7.1) v 2.8(5.1) \mathrm{g} / \mathrm{d}$, $\mathrm{p}<0 \cdot 2$. 
Table I Social characteristics of smokers and non-smokers by social class of partner ${ }^{\mathrm{a}}$. Values are percentages.

\begin{tabular}{|c|c|c|c|c|}
\hline \multirow{4}{*}{ - } & \multicolumn{4}{|l|}{ Social class } \\
\hline & \multicolumn{2}{|l|}{ Non-manual } & \multicolumn{2}{|l|}{ Manual } \\
\hline & Smokers & Non-smokers & Smokers & Non-smokers \\
\hline & $(n=22)$ & $(n=70)$ & $(n=61)$ & $(n=33)$ \\
\hline $\begin{array}{l}\text { Education }^{\mathrm{b}} \text { : } \\
\text { Higher } \\
\text { Intermediate } \\
\text { None } \\
\chi^{2}: \mathrm{p}<\end{array}$ & $\begin{array}{l}18 \\
55 \\
27 \\
20 \cdot 0: 0.001\end{array}$ & $\begin{array}{r}71 \\
22 \\
7\end{array}$ & $\begin{array}{l}1.5 \\
47 \\
51 \\
13 \cdot 8: 0.001\end{array}$ & $\begin{array}{r}2 \\
48 \\
28\end{array}$ \\
\hline $\begin{array}{l}\text { Housing tenure: } \\
\text { Owner } \\
\text { Renter } \\
\chi^{2}: p<\end{array}$ & $\begin{array}{l}50 \\
50 \\
11 \cdot 2: 0.001\end{array}$ & $\begin{array}{l}87 \\
13\end{array}$ & $\begin{array}{l}36 \\
72 \\
2 \cdot 2: 0 \cdot 2\end{array}$ & $\begin{array}{l}54 \\
46\end{array}$ \\
\hline $\begin{array}{l}\text { Income }{ }^{\mathrm{c}} \text { : } \\
\quad<f_{1} 125 / \text { week } \\
>f_{1} 125 / \text { week } \\
\chi^{2}: \mathrm{p}<\end{array}$ & $\begin{array}{l}31 \\
69 \\
4.5: 0.05\end{array}$ & $\begin{array}{l}10 \\
90\end{array}$ & $\begin{array}{l}56 \\
44 \\
4 \cdot 3: 0.05\end{array}$ & $\begin{array}{l}32 \\
68\end{array}$ \\
\hline $\begin{array}{l}\text { Employment: (p } \\
\text { Working } \\
\text { Not working } \\
\chi^{2}: p< \\
\end{array}$ & $\begin{array}{l}82 \\
18 \\
9 \cdot 4: 0.01 \\
\end{array}$ & $\begin{array}{r}97 \\
3\end{array}$ & $\begin{array}{l}81 \\
19 \\
0.8: 0.4 \\
\end{array}$ & $\begin{array}{r}91 \\
9\end{array}$ \\
\hline
\end{tabular}

SOCIAL CLASS

After adjusting for maternal height, social class of partner had a significant effect on intake of all nutrients except carbohydrate and carotene. Women with partners in social classes I+ II generally had the highest intakes and those in social classes IV $+\mathrm{V}$ had the lowest. These data have already been published. ${ }^{4}$

Although most of these social factors had highly significant associations with dietary intake on their own, many of them are intercorrelated and overlapping. To find out which factors had the greatest effects we did a stepwise multiple regression analysis including smoking, maternal education, income, marital status, paternal employment status, and maternal height as independent variables. From this equation, of the various social factors only income had a significant effect on energy intake, accounting for only $5 \%$ of the variance. Marital status and paternal employment had no effects on any nutrient intakes in this equation. Smoking was the most important factor in intakes of fibre, thiamine, vitamin $\mathrm{C}$, and vitamin $\mathrm{B} 6$, and also had
Table II Nutrient intakes per day at 28 weeks of pregnancy by income. Values are means ( $S D)$

\begin{tabular}{|c|c|c|c|c|c|}
\hline \multirow[b]{2}{*}{ Nutrient } & \multicolumn{4}{|c|}{ Income f/week (1984 values) } & \multirow[b]{2}{*}{$p^{a}<$} \\
\hline & $<£ 75(n=27)$ & $£ 75-124(n=44)$ & $£ 125-199(n=47)$ & $>£ 200(n=69)$ & \\
\hline $\begin{array}{l}\text { Fibre }(\mathbf{g})^{\star} \\
\text { Energy }(\mathrm{MJ})^{\star} \\
\text { Protein }(\mathbf{g}) \\
\text { Fat }(\mathbf{g}) \\
\text { Carbohydrate }(\mathbf{g})^{\star}\end{array}$ & $\begin{array}{c}14(5) \\
7 \cdot 8(2 \cdot 1) \\
65(14) \\
78(20) \\
236(83)\end{array}$ & $\begin{array}{l}15(6) \\
8 \cdot 1(2 \cdot 0) \\
68(19) \\
87(26) \\
230(56)\end{array}$ & $\begin{array}{c}19(8) \\
8 \cdot 2(1 \cdot 7) \\
72(13) \\
87(20) \\
229(61)\end{array}$ & $\begin{array}{l}20(7) \\
8.9(1 \cdot 7) \\
77(23) \\
97(23) \\
241(62)\end{array}$ & $\begin{array}{l}0.001 \\
0.05 \\
0.01 \\
0.01 \\
0.8\end{array}$ \\
\hline $\begin{array}{l}\text { Calcium (mg) } \\
\text { Iron (mg) } \\
\text { Copper }(\mathbf{m g})^{\star} \\
\text { Zinc }(\mathbf{m g})^{\star}\end{array}$ & $\begin{array}{c}833(312) \\
9 \cdot 0(2 \cdot 2) \\
1 \cdot 21(0 \cdot 33) \\
8 \cdot 5(2 \cdot 2)\end{array}$ & $\begin{array}{l}936(288) \\
9 \cdot 8(3 \cdot 2) \\
1 \cdot 35(0 \cdot 48) \\
9 \cdot 0(3 \cdot 4)\end{array}$ & $\begin{array}{l}994(275) \\
11.4(4 \cdot 2) \\
1.45(0.61) \\
9.9(2 \cdot 4)\end{array}$ & $\begin{array}{c}1025(300) \\
12 \cdot 6(3 \cdot 7) \\
1 \cdot 64(0 \cdot 62) \\
10 \cdot 2(2 \cdot 7)\end{array}$ & $\begin{array}{l}0.05 \\
0.001 \\
0.01 \\
0.01\end{array}$ \\
\hline 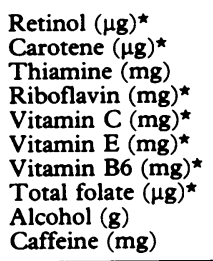 & $\begin{array}{c}362(225) \\
851(711) \\
1 \cdot 13(0 \cdot 38) \\
1 \cdot 66(0.63) \\
48(31) \\
3 \cdot 1(1 \cdot 3) \\
1 \cdot 03(0 \cdot 25) \\
131(38) \\
1 \cdot 2(2 \cdot 6) \\
392(279)\end{array}$ & $\begin{array}{c}475(238) \\
1070(752) \\
1.12(0.32) \\
1.79(0.58) \\
56(38) \\
4 \cdot 2(1.7) \\
1.10(0.30) \\
152(53) \\
2.2(4 \cdot 7) \\
385(233) \\
\end{array}$ & $\begin{array}{c}696(811) \\
1120(560) \\
1.23(0.32) \\
2.02(0.59) \\
66(40) \\
4.7(1.6) \\
1 \cdot 18(0 \cdot 30) \\
177(65) \\
3.8(7.8) \\
351(209) \\
\end{array}$ & $\begin{array}{c}715(585) \\
1274(671) \\
1 \cdot 33(0 \cdot 32) \\
2 \cdot 10(0 \cdot 63) \\
85(50) \\
5 \cdot 3(1.8) \\
1.30(0 \cdot 35) \\
186(54) \\
4 \cdot 5(6 \cdot 4) \\
329(145) \\
\end{array}$ & $\begin{array}{l}0.001 \\
0.01 \\
0.01 \\
0.01 \\
0.001 \\
0.001 \\
0.01 \\
0.001 \\
0.07 \\
0.4 \\
\end{array}$ \\
\hline
\end{tabular}

a Significance of difference using two way analysis of variance controlling for maternal height

* Data logarithmically transformed for analysis.
Table III Nutrient intakes per day in prgnancy by maternal educational qualifications. Values are means ( $S D)$

\begin{tabular}{|c|c|c|c|c|}
\hline \multirow[b]{2}{*}{ Nutrient } & \multicolumn{3}{|c|}{ Level of educational qualification } & \multirow[b]{2}{*}{$p^{\mathbf{a}}<$} \\
\hline & Higher $(n=63)$ & $\begin{array}{l}\text { Intermediate } \\
(n=79)\end{array}$ & None $(n=63)$ & \\
\hline $\begin{array}{l}\text { Fibre }(\mathbf{g})^{\star} \\
\text { Energy }(\mathbf{M J})^{\star} \\
\text { Protein }(\mathbf{g}) \\
\text { Fat }(\mathbf{g})^{\star} \\
\text { Carbohydrate }(\mathbf{g})^{\star}\end{array}$ & $\begin{array}{c}23(8) \\
8 \cdot 6(1 \cdot 5) \\
77(15) \\
93(22) \\
232(50)\end{array}$ & $\begin{array}{l}17(7) \\
8 \cdot 5(2 \cdot 2) \\
72(17) \\
91(26) \\
237(74)\end{array}$ & $\begin{array}{l}14(5) \\
8 \cdot 1(1 \cdot 8) \\
68(16) \\
84(21) \\
234(68)\end{array}$ & $\begin{array}{l}0.001 \\
0 \cdot 6 \\
0.05 \\
0 \cdot 2 \\
0.5\end{array}$ \\
\hline $\begin{array}{l}\text { Calcium (mg) } \\
\text { Iron }(\mathrm{mg})^{\star} \\
\text { Copper }(\mathrm{mg})^{\star} \\
\text { Zinc }(\mathrm{mg})^{\star}\end{array}$ & $\begin{array}{c}1030(275) \\
13 \cdot 2(3.5) \\
1.66(0 \cdot 54) \\
10 \cdot 7(2 \cdot 7)\end{array}$ & $\begin{array}{c}996(317) \\
11 \cdot 0(4 \cdot 2) \\
1 \cdot 50(0 \cdot 64) \\
9 \cdot 7(3 \cdot 1)\end{array}$ & $\begin{array}{c}880(300) \\
9 \cdot 4(2 \cdot 4) \\
1 \cdot 29(0.52) \\
8 \cdot 4(2 \cdot 1)\end{array}$ & $\begin{array}{l}0.05 \\
0.001 \\
0.005 \\
0.001\end{array}$ \\
\hline $\begin{array}{l}\text { Retinol }(\mu \mathrm{g})^{\star} \\
\text { Carotene }(\mu \mathrm{g})^{\star} \\
\text { Thiamine }(\mathrm{mg}) \\
\text { Riboflavin (mg) } \\
\text { Vitamin C }(\mathrm{mg})^{\star} \\
\text { Vitamin E (mg) } \\
\text { Vitamin B6 (mg) } \\
\text { Total folate }(\mu \mathrm{gg})^{\star} \\
\text { Alcohol }(\mathrm{g}) \\
\text { Caffeine (mg) }\end{array}$ & $\begin{array}{c}712(621) \\
1421(640) \\
1.34(0.31) \\
2 \cdot 14(0.62) \\
92(45) \\
5.7(1.8) \\
1.34(0.31) \\
199(53) \\
5.1(8.3) \\
309(157)\end{array}$ & $\begin{array}{c}593(571) \\
1140(754) \\
1.23(0 \cdot 35) \\
1.95(0 \cdot 63) \\
66(47) \\
4.5(1 \cdot 7) \\
1 \cdot 15(0 \cdot 34) \\
166(59) \\
2 \cdot 4(4 \cdot 5) \\
346(203)\end{array}$ & $\begin{array}{c}461(419) \\
936(721) \\
1 \cdot 10(0.33) \\
1 \cdot 75(0.62) \\
48(30) \\
3 \cdot 6(1 \cdot 2) \\
1 \cdot 06(0 \cdot 28) \\
141(52) \\
2 \cdot 4(4 \cdot 7) \\
426(242)\end{array}$ & $\begin{array}{l}0.05 \\
0.001 \\
0.01 \\
0.01 \\
0.001 \\
0.001 \\
0.001 \\
0.01 \\
0.05 \\
0.001\end{array}$ \\
\hline
\end{tabular}

a Significance of difference using two way analysis of variance controlling for maternal height $\star$ Data logarithmically transformed for analysis. significant effects on the intakes of iron, copper, vitamin $\mathrm{E}$ and folate. Maternal education was the most important factor in intake of iron, vitamin $\mathrm{E}$ and folate, but also had a significant effect on intakes of other minerals and vitamins. Income had an effect on almost all nutrients. These factors together, plus maternal height, accounted for between $4 \%$ (carbohydrate) and $32 \%$ (fibre) of the variance in intake of nutrients.

When housing tenure and social class were entered into the equation, the effects of maternal education and smoking remained but income appeared to be a significant factor only for retinol, its effects on intake of other nutrients being no longer significant (table IV). Income was the only significant factor in alcohol intake but only accounted for $4 \%$ of the variance. Housing tenure and social class were significant factors in intakes of both macro- and micronutrients. Addition of these factors to the equation only slightly increased the amount of the variance in intakes explained by the model-eg, from $32^{\circ}$ o to $35^{\circ}$ o 
Table IV The effects of social factors on nutrient intakes-stepwise multiple regression for each nutrient
Table $V$ Social factors in nutrient densitystepwise multiple regression for each nutrient

\begin{tabular}{|c|c|c|c|c|c|c|c|}
\hline Nutrient & $\underset{\beta^{\text {Smoking }}}{\text { Smokn }}$ & $\underset{\beta}{E d u c a t i o n}{ }^{\mathbf{a}}$ & ${ }_{\beta}^{\text {Income }}$ & ${ }_{\boldsymbol{\beta}}^{\text {Tenure }}$ & Social class $^{\mathbf{c}}$ & ${ }_{\beta}^{H e i g h t}$ & $R^{2 \mathrm{e}}$ \\
\hline $\begin{array}{l}\text { Fibre } \\
\text { Energy } \\
\text { Protein } \\
\text { Fat } \\
\text { Carbohydrate }\end{array}$ & $\begin{array}{l}-0.26 \\
= \\
= \\
=\end{array}$ & $\begin{array}{l}0.20 \\
= \\
= \\
-\end{array}$ & $\begin{array}{l}- \\
= \\
=\end{array}$ & $\begin{array}{l}0.20 \\
-0.33 \\
0.18 \\
-\end{array}$ & $\begin{array}{l}- \\
0.28 \\
\overline{0} \cdot 19 \\
0 \cdot 15\end{array}$ & $\begin{array}{l}0 \cdot 15 \\
0 \cdot 17 \\
- \\
\overline{0} \cdot 19\end{array}$ & $\begin{array}{l}0.35 \\
0.12 \\
0.11 \\
0.11 \\
0.07\end{array}$ \\
\hline $\begin{array}{l}\text { Calcium } \\
\text { Iron } \\
\text { Copper } \\
\text { Zinc }\end{array}$ & $\begin{array}{l}-\overline{0} \cdot 18 \\
-0 \cdot 17 \\
-\end{array}$ & $\begin{array}{l}\overline{0} \cdot 19 \\
\overline{0} \cdot 18\end{array}$ & $\begin{array}{l}- \\
\bar{z} \\
-\end{array}$ & $\begin{array}{l}\overline{0} \\
\overline{0} \cdot 19 \\
0 \cdot 23\end{array}$ & $\begin{array}{l}0.24 \\
\overline{0} \cdot 25\end{array}$ & $\begin{array}{l}- \\
0.15 \\
0.20 \\
0.15\end{array}$ & $\begin{array}{l}0.06 \\
0 \cdot 27 \\
0 \cdot 19 \\
0 \cdot 18\end{array}$ \\
\hline $\begin{array}{l}\text { Retinol } \\
\text { Carotene } \\
\text { Thiamine } \\
\text { Riboflavin } \\
\text { Vitamin C } \\
\text { Vitamin E } \\
\text { Vitamin B6 } \\
\text { Total folate } \\
\text { Alcohol } \\
\text { Caffeine }\end{array}$ & $\begin{array}{l}-\overline{0} .16 \\
-0.20 \\
-\overline{0} \\
-\overline{0} \\
-0.22 \\
-0.18 \\
\overline{0} .59\end{array}$ & $\begin{array}{l}\overline{0} \\
0 \cdot 25 \\
\overline{-} \\
0 \cdot 24 \\
0 \cdot 33 \\
\overline{0} \cdot 14 \\
\overline{-}\end{array}$ & $\begin{array}{l}0 \cdot 33 \\
\overline{-} \\
= \\
= \\
= \\
\overline{0} \\
0 \cdot 19 \\
-\end{array}$ & $\begin{array}{l}\overline{0} \cdot 16 \\
0 \cdot 27 \\
\overline{0} \\
0 \cdot 16 \\
0 \cdot 23 \\
0 \cdot 16 \\
0 \cdot 19 \\
- \\
-\end{array}$ & $\begin{array}{l}\bar{z} \\
\overline{0} \\
\overline{0} \cdot 33 \\
\overline{0} \\
\overline{0} \cdot 23 \\
0 \cdot 17 \\
\overline{0} \cdot 18\end{array}$ & $\begin{array}{l}\overline{-} \\
\overline{-} \\
0 \cdot 15 \\
\overline{0} \cdot 14 \\
\overline{-} \\
\overline{-} \\
-\end{array}$ & $\begin{array}{l}0.11 \\
0.21 \\
0 \cdot 16 \\
0 \cdot 15 \\
0.31 \\
0 \cdot 29 \\
0 \cdot 22 \\
0.27 \\
0.04 \\
0.31\end{array}$ \\
\hline
\end{tabular}

a Positive coefficient indicates increasing intake with increasing level of education

b Owner occupiers compared to renters

c Positive coefficient indicates increased intake in social classes I + II compared to social class III and classes IV +V

$\mathrm{d}_{\beta}$ is standardised regression coefficient which have been used to enable comparison between coefficients as the variables in the equation have different units.

${ }^{e}$ Cumulative for all factors in the model

for fibre, and from $24 \%$ to $29 \%$ for total folate. For many it made no difference.

When the same regression was done using nutrient densities as the dependent variables, smoking and maternal education were the only variables which explained significant amounts of the variance in nutrient densities; income only had a negative effect on carbohydrate density, and a positive effect on fat and retinol intakes; social class had no effects on the nutrient density of intake of any nutrients (table V).

\section{Discussion}

We have looked at both quantity and quality of diet in this analysis. Although the social factors considered-smoking, maternal education, income, marital status, housing tenure, social class-were all found to be associated with variation in dietary intake when considered on their own, stepwise regression indicated that only the general social factors of housing tenure and social class had any significant association with overall quantity, ie, macronutrients-energy, protein, and fat (excluding fibre). Neither smoking nor maternal education explained any of the variance in macronutrient intake. However the strongest determinants of quality of diet (or nutrient density) were smoking and maternal education, while income, housing tenure, and social class made very little contribution.

When housing tenure and social class were excluded from the analysis a comparable proportion of the variance in intake of most nutrients, particularly macronutrients, was explained by income variation. This suggests that the effects of income and social class and housing tenure on dietary intake are difficult to disentangle in an analysis of this sort.

The combination of smoking and maternal education as the only significant social determinants of dietary quality is interesting. Other studies have suggested that low income women have poorer diets than other women, ${ }^{2}$ and one would expect that where money is short the variety and quality of food consumed, as well as the quantity, would be reduced. It was surprising to find therefore that neither income nor social class had any effect on dietary quality in this analysis. Low income, poor education, and smoking are often associated; thus the significance of income may have been overemphasised in those studies. The role of smoking as a determinant of dietary quality is hard to explain. It is probable that women who are still smoking heavily in pregnancy (despite the current antismoking

\begin{tabular}{|c|c|c|c|c|c|c|}
\hline Nutrient $^{c}$ & $\begin{array}{l}\text { Smoking } \\
\beta^{d}\end{array}$ & $\begin{array}{l}\text { Education }^{\mathbf{a}} \\
\boldsymbol{\beta}\end{array}$ & $\begin{array}{l}\text { Income } \\
\beta\end{array}$ & $\begin{array}{l}\text { Tenure }^{\mathrm{b}} \\
\beta\end{array}$ & $\begin{array}{l}\text { Social class } \\
\beta\end{array}$ & $R^{2 \mathrm{e}}$ \\
\hline $\begin{array}{l}\text { Fibre } \mathbf{g} / \mathbf{M J} \\
\text { Protein } \mathbf{g} / \mathbf{M J} \\
\text { Fat } \mathbf{g} / \mathbf{M J} \\
\text { Carbohydrate } \mathrm{g} / \mathrm{MJ}\end{array}$ & $\begin{array}{l}-0 \cdot 31 \\
= \\
=\end{array}$ & $\begin{array}{l}0.31 \\
= \\
=\end{array}$ & $\begin{array}{c}\overline{-} \\
\overline{0} \cdot 18 \\
-0.24\end{array}$ & $\begin{array}{l}\overline{0} \cdot 16 \\
\overline{-}\end{array}$ & $\begin{array}{l}\bar{y} \\
\bar{z}\end{array}$ & $\begin{array}{l}0.29 \\
0.02 \\
0.03 \\
0.06\end{array}$ \\
\hline $\begin{array}{l}\text { Calcium mg/MJ } \\
\text { Iron mg/MJ } \\
\text { Copper mg/MJ } \\
\text { Zinc mg/MJ }\end{array}$ & $\begin{array}{l}-\overline{0} \cdot 21 \\
-0 \cdot 23 \\
-\end{array}$ & $\begin{array}{l}0.16 \\
0.29 \\
-0.30\end{array}$ & $\begin{array}{l}\bar{z} \\
\bar{z}\end{array}$ & $\begin{array}{l}\bar{z} \\
\bar{y}\end{array}$ & $\begin{array}{l}\bar{z} \\
\bar{z}\end{array}$ & $\begin{array}{l}0.03 \\
0.19 \\
0.05 \\
0.09\end{array}$ \\
\hline $\begin{array}{l}\text { Retinol } \mu \mathrm{g} / \mathrm{MJ} \\
\text { Carotene } \mu \mathrm{g} / \mathrm{MJ} \\
\text { Thiamine } \mathrm{mg} / \mathrm{MJ} \\
\text { Riboflavin } \mathrm{mg} / \mathrm{MJ} \\
\text { Vitamin } \mathrm{C} \mathrm{mg} / \mathrm{MJ} \\
\text { Vitamin } \mathrm{Eg} / \mathbf{M J} \\
\text { Vitamin } \mathrm{B} 6 \mathrm{mg} / \mathrm{MJ} \\
\text { Total folate } \mu \mathrm{g} / \mathbf{M J}\end{array}$ & $\begin{array}{l}- \\
-\overline{0} \\
-0.29 \\
-0.21 \\
-0.19 \\
-0.22 \\
-0.24\end{array}$ & $\begin{array}{l}\overline{0} \\
\overline{0} \\
\bar{y} \\
0.26 \\
0.41 \\
0.21 \\
0.26\end{array}$ & $\begin{array}{l}0 \cdot 16 \\
- \\
= \\
= \\
= \\
= \\
-\end{array}$ & $\begin{array}{l}\bar{z} \\
\bar{z} \\
\bar{z} \\
\bar{z} \\
\bar{y}\end{array}$ & $\begin{array}{l}\bar{z} \\
\bar{z} \\
\bar{z} \\
\bar{z} \\
\bar{z}\end{array}$ & $\begin{array}{l}0.03 \\
0.07 \\
0.08 \\
0.05 \\
0.18 \\
0.28 \\
0.11 \\
0.19\end{array}$ \\
\hline
\end{tabular}


advice) are those least likely to be receptive to health education programmes in general, and are therefore least likely to have a high quality of diet. Women with poor educational attainment may also be less likely to be receptive to the kind of educational advice that is generally given about diet in pregnancy. These groups should perhaps be specifically targeted for education and advice that is appropriate to their financial circumstances.

Although neither income, social class nor housing tenure had much effect on dietary quality, they did explain a significant amount of the variation in quantity of intakes of both macroand micronutrients. Low income women (many of whom are single), home renters, or women of low social class had mean energy intakes that were less than $80 \%$ of the recommended daily intake ${ }^{31}$ for pregnancy. Using the unstandardised regression coefficients for each variable in the equation we calculated the theoretical values of predicted intakes of nutrients by different groups in order to be able to compare diets of higher income well educated non-smokers with low income, poorly educated smokers. Using these intakes we found a calculated reduction of $67^{\circ}$ in vitamin $C$ intakes. Vitamin $C$ has been suggested as being a good indicator of general quality of diet. $^{32}$ This combination of social factors similarly reduced intakes of fibre (by $45^{\circ} \mathrm{o}$ ), folate (by $41 \%$ ), vitamin $\mathrm{E}$ (by $40 \%$ ), and iron (by $33^{\circ}$ ). Poor nutritional status in pregnancy may have adverse consequences for the health and well being of both the mother and the baby. There is little reason to suppose that women radically change their diets in pregnancy (except in early pregnancy when nausea is common). It is therefore a reasonable assumption that low income, poorly educated smokers will continue to have a poor quality of diet postpartum. Poorer diet may have an important role in the higher morbidity and mortality of smokers of low social class and low income. ${ }^{11}$

Although the factors considered in this analysis showed effects that were highly significant statistically, they accounted for a relatively small amount of the variance in intakes. Social factors explained more of the variance in intakes of micronutrients and the highest $\mathbf{R}^{2}$ values (of combined social factors) were for those nutrients that have had a considerable amount of media coverage in recent years and/or have been the subject of health education campaigns, eg fibre $(35 \%)$, vitamin $\mathrm{E}$ (in polyunsaturated fats) $(29 \%$ ), vitamin $\mathbf{C}(31 \%)$; thus the high $\mathbf{R}^{2}$ values may reflect the differential impact of these programmes on different sections of the population. Social factors (and maternal height) explained less than $12^{\circ}$ o of the variance of the macronutrients protein, fat and carbohydrate, and overall energy intake. Individual variations in energy expenditure and metabolic rates might contribute to the variances of these intakes in the population.

All women at St George's Hospital and at many hospitals throughout the country get routine dietary advice when they book in to the antenatal clinics. Our data suggest that specifically targeting pregnant women who are smokers, accommodation renters, and/or of minimum education (or perhaps low social class where other information is not available) for dietary advice would be appropriate, as well as offering advice on giving up smoking. This may also have long term health benefits.

We would like to thank Professors Trussell and Chamberlain and the antenatal clinic staff for facilitating the study, Mrs A Shaw and Ms J Griffin for their help in collecting of dietary data. Financial support was received from a consortium of American Tobacco Companies.

1 Smithells RW, Ankers C, Carver M, Lennon D, Schorah CJ, Sheppard S. Maternal nutrition in early pregnancy. $B$ Nutr 1977; 38: 497-506.

2 Doyle W, Crawford MA, Laurence BM, Drury P. Dietary survey during pregnancy in a low socio-economic group. Hum Nutr Appl Nutr 1982; 36A: 95-106.

3 Thomson AM. Diet in pregnancy: 1 Dietary survey technique and the nutrititive value of diets taken by primigravidae. $\mathrm{Br}$ F Nutr 1958; 12: 446-61

4 Haste FM, Brooke OG, Anderson HR, Bland JM, Shaw A Griffin J, Peacock JL. Nutrient intakes during pregnancy: observations on the influence of smoking and social class. Am $f$ Clin Nutr 1990; 51: 29-36.

5 Ministry of Agriculture Fisheries and Food. National Food Survey. London: HMSO, 1985.

6 Braddon FEM, Wadsworth MEJ, Davies JMC, Cripps HA. Braddon FEM, Wadsworth MEJ, Davies JMC, Cripps HA.
Social and regional differences in food and alcohol cocial and regional differences in food and alcohol consumption and their measurement in a national birth

7 World Health Organization. Prevention of coronary heart disease. Technical Report Series 678. Geneva: WHO, 1982 8 World Health Organization. Primary prevention of essential hypertension. Technical Report Series 686. Geneva: WHO, 1983.

9 Insulin dependent? (Editorial) Lancet 1985; ii: 809-10.

10 Doll R, Peto R. The causes of cancer. Oxford: Oxford University Press, 1981.

11 Townsend $\mathbf{P}$, Davidson $\mathbf{N}$, Whitehead $\mathbf{M}$. Inequalities in health. The Black Report and The Health Divide. London: Pelican, 1988.

12 Metcoff J, Costiloe JP, Crosby W, et al. Maternal nutrition and fetal outcome. Am $₹$ Clin Nutr 1981; 34: 708-21.

13 Wideman GL, Baird GH, Bolding OT. Ascorbic acid deficiency and premature rupture of membranes. $A m \mathcal{J}$ deficiency and premature rupture
Obstet Gynecol 1964; 88: 592-5.

14 Rolschau J, Date J, Kristoffersen K. Folic acid supplement and intrauterine growth. Acta Obstet Gynecol Scand 1979, 58: $343-6$.

15 Baumslag $N$. Reduction in incidence of prematurity by folic acid supplements in pregnancy. $B r$ Med f 1970; i: 16-17. 16 Hibbard BM. Folates and the fetus. S Afr Med F 1975; 49 1223-6.

17 Meadows NJ, Smith MF, Keeling PWN, Ruse W, Day J, Scopes JW. Zinc and small babies. Lancet 1981; ii: 1135-7.

18 Patrick J, Dervish G, Gillieson M. Zinc and small babies. Lancet 1982; i: 169-70 (letter).

19 Swanson CA, King JC. Zinc and pregnancy outcome. $A m \mathcal{J}$ Clin Nutr 1987; 46: 763-71.

20 Kuhnert BR, Kuhnert PM, Debanne S, Williams TG. The relationship between cadmium, zinc and birthweight in women who smoke. Am $\mathcal{f}$ Obstet Gynecol 1987; 157 1247-51.

21 Wells JL, James DK, Luxton R, Pennock CA. Maternal leucocyte zinc deficiency at the start of the third trimester as a predictor of foetal growth retardation. $\mathrm{Br}$ Med $\mathcal{F} 1987$; 294: 1054-6.

22 Prentice AM, Whitehead RG, Watkinson M, Lamb WH, Cole TJ. Prenatal dietary supplementation in African women and birthweight. Lancet 1983; i: 489-92.

23 Baird D. Epidemiology of low birthweight; changes in the incidence in Aberdeen 1948-1972. F Biosoc Sci 1974; 6: 323-43.

24 Rush D. Examination of the relationship between birthweight, cigarette smoking during pregnancy and

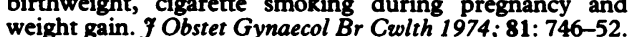

25 wrooke OG, Anderson HR, Bland JM, Peacock JL, 746-52. $\mathrm{CM}$. The effects on birthweight of smoking, alcohol, caffeine, socio-economic factors and psychosocial stress. $\mathrm{Br}$ Med 7 1989; 298: 795-801.

26 Office of Population Censuses and Surveys. Classification of occupations. London: HMSO, 1980.

27 Paul AA, Southgate DAT. McCance $\&$ Widdowson's "The composition of foods", 4th revised edition. London: HMSO, 1978 .

28 Burg AW. Effects of caffeine on the human system. Tea Coffee Trade $\mathcal{F} 1975 ; 147: 40-2$, and 88

29 Gilbert RM, Marshmam JA, Schweider M, Berg R. Caffeine content of beverages as consumed. Can Med Assoc 71976 ; 114: 205-8.

30 Graham DM. Caffeine-its identity, dietary sources, intake and biological effects. Nutr Rev 1978; 36: 97-102.

31 Department of Health and Social Security. Recommended daily amounts of nutrients for groups of people in the UK. London: HMSO, 1979 .

32 Guthrie HA. Nutritional status measures as predictors of nutritional risk in the ten state nutrition survey. Nut Rep Int 1976; 14: 299-305. 